\title{
GREEN GARDENS AZORES PROJECT: A BRIEF CHARACTERIZATION OF THE VASCULAR FLORA IN THE AZORES' HISTORICAL GARDENS
}

\author{
Maria João Pereira*, Raimundo Quintal**, \\ Carina Costa*** \& Isabel Albergaria*
}

\section{Abstract}

The Green Gardens Azores Project is part of the action plan for tourism development in Portugal (2014-2020) aiming to integrate the Azorean Gardens in the circuit of international 'Garden Tourism'. With that purpose we built a checklist of the vascular plants cultivated in 8 Azorean Historical Gardens. The analysis of this checklist reveals a richness of 1884 specific and infra-specific taxa, hybrids and cultivars. This richness is represented by 168 families, 514 genera, 991 species, 288 hybrids and 958 cultivars. Camellia hybrids correspond to $60 \%$ of all the hybrids and Camellia cultivars represent $71 \%$ of all the cultivars. Zamiaceae is the family best represented with 73 species while the best represented genera are Encephalartos with 48 species and Camellia with 45 species. The presence of 5 species extinct in the wild and 96 threatened species in the Azorean Gardens stresses the role of the Gardens in the Conservation of World Flora.

KEYwORDs: Azores, garden flora, garden tourism.

\section{EL PROYECTO «JARDINES VERDES DE AZORES»: BREVE CARACTERIZACIÓN DE LA FLORA VASCULAR DE LOS JARDINES HISTÓRICOS DE AZORES}

\section{RESUMEN}

El proyecto «jardines verdes de Azores» es parte de un plan de acción para el desarrollo turístico de Portugal (2014-2020) pretendiendo integrar estos jardines en el circuito internacional de jardines turísticos. Con este propósito hicimos la redacción de un listado de plantas vasculares cultivadas en ocho jardines históricos de Azores. El análisis del listado señaló una riqueza de 1884 categorías específicas, infraespecíficas, híbridos y cultivares. Esta riqueza está representada por 168 familias, 514 géneros, 991 especies, 288 híbridos y 958 cultivares. El género Camellia contribuye con un $60 \%$ de todos los híbridos y un $71 \%$ de todos los cultivares. Zamiaceae es la familia mejor representada con 73 especies, mientras que los géneros mejor representados son Encephalartos con 48 y Camellia con 45 especies. La presencia de cinco especies extintas en la naturaleza y 96 especies amenazadas en los jardines de Azores subrayan el papel que estos juegan en la conservación de la flora mundial. Palabras Clave: Azores, flora de jardín, turismo de jardines. 


\section{INTRODUCTION}

For their historical, botanical, and landscape value, the gardens of the Azores are an important heritage that can answer to the global demand of 'Garden Tourism' (Benfield 2013; Čakovská 2018). If we want to understand the economic impact of garden tourism, we can take as an example the fact that in 2014, 20 million paid entries were registered in the National Trust's British Gardens (National Trust 2014). Until now tourism at the Azores has been grounded on 'Nature Tourism' and 'Adventure Tourism' (Fraga 2014; Governo dos Açores 2016; Guerreiro 2017; Ponte et al. 2018). Nevertheless, there are evident advantages in developing the segment of garden tourism at the Azores, not only because garden tourism is suitable for a greater number of people than adventure or nature tourism, but also because these segments of tourism represent complementary niche markets that are not associated with mass tourism. In the Azores the growing world demand regarding the uses of gardens, has corresponded: to an increasing number of visits and visitors (SDEA 2018; SREA 2019); to the acknowledgment of Terra Nostra Garden international distinctions (Cox et al. 2014; ICS 2019); and to the organization of thematic guided tours (Haslemere Travel 2013), International Meetings of Ancient Camellias at Furnas in São Miguel Island (ICS 2007), and several scientific, educational and cultural events in the gardens.

The present study resulted from the Azores Green Gardens Project implementation (Green Gardens Azores 2019). This project is part of the Action Plan for Tourism Development in Portugal and aims to integrate the Azorean Gardens in the Circuit of International Garden Tourism. The project, co-financed by the European Regional Development Fund through the Operational Program 'Azores2020', is promoted by the Azores Tourism Observatory, with the Azores University and Gaspar Frutuoso Institution as co-promotors, and involves several other Azorean private and public institutions. Broadly this project is developed in two steps: a) gardens selection and characterization and b) design of communication and dissemination strategies and their implementation and evaluation. To this project several sites were selected, including Faial Botanic Garden, Pinhal da Paz Park, and two vineyards at Pico and Terceira Islands; but this study aimed the characterization of the vascular flora present only on the $19^{\text {th }}$ century historical gardens: one from Terceira Island (Duque da Terceira Garden) and 7 from São Miguel Island (António Borges Garden, Sant'Ana Garden, José do Canto Garden, Azores University Garden, José do Canto Woodland Garden, Beatriz do Canto Park and Terra Nostra Garden) (figure 1).

* Biotechnology Centre of Azores, Universidade dos Açores, Azores, Portugal. Corresponding author: maria.jb.trota@uac.pt.

** Centre for Geographical Studies, Instituto de Geografia e Ordenamento do Território, Universidade de Lisboa, Lisboa, Portugal.

*** Terra Nostra Garden Hotel, Azores, Portugal.

**** CHAM, Universidade dos Açores, Azores, Portugal. 


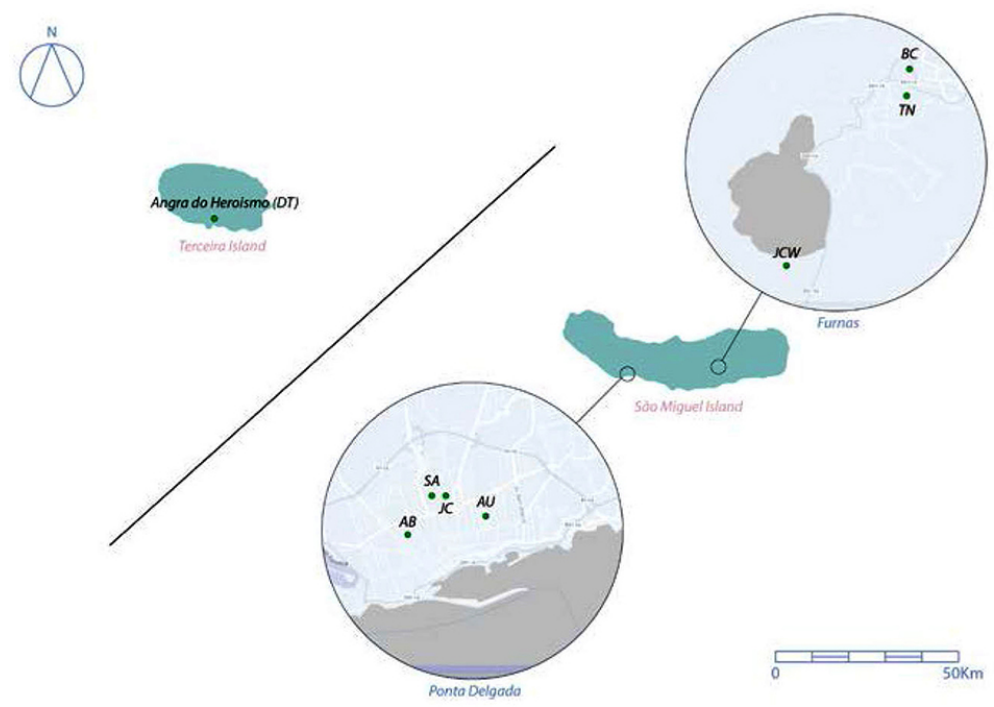

Figure 1. Locations of the gardens at Terceira and Sáo Miguel islands: DT- Duque da Terceira Garden; AB - António Borges garden; SA - Sant'Ana garden; JC - José do Canto garden; AU Azores University Garden; JCW - José do Canto Woodland Garden; BC - Beatriz do Canto park; TN - Terra Nostra (courtesy of Ricardo Cruz architect).

\section{MATERIAL AND METHODS}

\subsection{STUDY SITES}

The criteria to select the Azorean gardens and parks were the following: to be visitable, and accessible, possess maintenance services and facilities, and have historical, botanical, and landscape interest. Regarding the selected gardens, the first one to be established as a romantic garden, was the summer house called "Yankee Hall" in Furnas which became the genesis of the present Terra Nostra Garden (Carvalho 2017). All the other gardens are formed practically in the second half of the $19^{\text {th }}$ century (Albergaria 2005). José do Canto Woodland Garden is the one situated at the higher altitude, between 283 and 330 m, while the António Borges Garden is the garden located at the lowest altitude $(20 \mathrm{~m})$. José do Canto Woodland Garden has also the largest area with 120 ha, while the Azores University Garden has the smallest area only with 1.5 ha (table 1 ).

Regarding the gardens typology, the Terra Nostra Garden in its origin it's a romantic garden, but with time several elements were transformed or added (Albergaria 2000). The original cold water lake with canoes was replaced with a natural thermal water pool. Other elements were added as the memorial lane, and later, the Victoria cruziana A.D. Orb. tank, some animals covered with creeping plants and 
new formal flower beds (Albergaria 2000; Carvalho 2017). The Garden of Sant'Ana brings together the romantic elements such as the lake with the anchorage point and formal elements like the 'parterre' in front of the palace, assuming itself as a botanical park with a collection of exotic species (Albergaria 2000). José do Canto Garden is also a botanical park in the sense that it maintains and increases their plant collection, but we can also find the original romantic and formal elements as the small pond and the rose garden, respectively (Albergaria 2000). José do Canto Woodland Garden corresponds to a vast area of spontaneous native and exotic naturalized or invasive species, coexisting with the exotic species initially planted by José do Canto (Albergaria 2000). Beatriz do Canto Park, António Borges Garden, and Azores University Garden are in their essence romantic gardens with more or less sophisticated water elements from the water stream with small cascades and a water wheel at Beatriz do Canto Park to small artificial lake at Azores University Garden (Albergaria 2000). The artificial volcanic rock grottoes are also romantic features present symbolically at Azores University Garden but much more elaborated at António Borges Garden (Albergaria 2000). Finally, the typology of Duque da Terceira Garden, is that one of a public garden with an access to the higher part of the town and to the monument 'Alto da Memória' (Albergaria 2005).

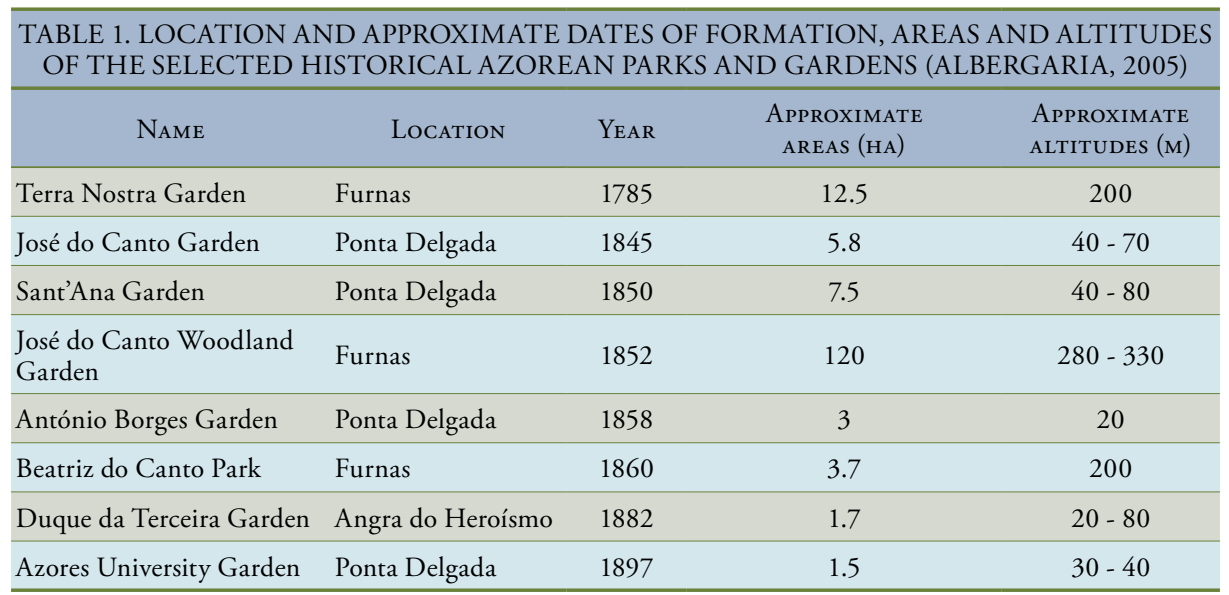

\subsection{Plant list database and plant identifications}

An excel worksheet was used to create the plant list database for the Azorean historical gardens. Plant names were gathered from published and non-published plant lists of the selected gardens and parks (table 2). Plant names were checked for synonyms using 'The Plant List' (2013) data base; we adopted the scientific names with the status 'Accepted' (e.g. Araucaria heterophylla (Salisb.) Franco). For the 141 taxa names with 'Unresolved name' status (e.g. Viburnum treleasei Gand.), we analysed the respective recent published scientific taxonomic works (e.g. Moura et al. 2015). Also, from 2016 to 2018 several visits were made to the listed gardens 
and parks; during the visits digital images of selected specimens were taken and when needed parts of the plants were collected for posterior identification using regional floras, field guides, scientific papers and electronic databases. Table 3 lists the information gathered in the plant list database for the Azorean historical gardens.

\begin{tabular}{|c|c|c|}
\hline \multicolumn{3}{|c|}{$\begin{array}{l}\text { TABLE 2. DATA SOURCES FOR PLANT NAMES (HD - HISTORICAL DOCUMENT; } \\
\text { ITD - INTERNAL TECHNICAL DOCUMENT; B - BOOK) }\end{array}$} \\
\hline NAME & Available lists & TyPe OF DOCUMENT \\
\hline Terra Nostra Garden & Costa 2018 - ITD & ITD \\
\hline \multirow[t]{2}{*}{ José do Canto Garden } & Canto 1856 & HD \\
\hline & Quintal and Braga 2018 & B \\
\hline \multirow[t]{2}{*}{ Sant'Ana Garden } & Canto 1856 & HD \\
\hline & Pacheco 2016 & ITD \\
\hline José do Canto Woodland Garden & Quintal 2015, 2018 & ITD \\
\hline António Borges Garden & Topiaris 2008 & ITD \\
\hline Beatriz do Canto Park & Quintal 2018 & ITD \\
\hline Duque da Terceira Garden & CMAH 2017 & ITD \\
\hline Azores University Garden & Pereira et al. 2010 & B \\
\hline
\end{tabular}

\begin{tabular}{ll}
\hline \multicolumn{2}{c}{ TABLE 3. INFORMATION AT AZORES' HISTORICAL GARDENS PLANT DATABASE } \\
\hline \multicolumn{1}{c}{ FlORISTIC COMPOSITION } \\
\hline Name status & Accepted / Unresolved \\
\hline Species Conservation Status & IUCN categories \\
\hline Species status to the Azores & Exotic / Native \\
\hline Group & Pteridophyta / Pinophyta / Dicotyledon / Monocotyledon \\
\hline Taxon categories & Family / Genus / Species / Subspecies / Variety / Form / Hybrid \\
\hline Cultivars & Species cultivars / Species variety cultivars / Hybrid cultivars \\
\hline Origin & Horticultural / Natural [Native of (geographic region)] \\
\hline Habit growth form & Herbs / Shrubs / Trees / Palms / Climbers / Ferns \\
\hline
\end{tabular}

Data analysis. To the 8 historical gardens the plant list resulted in a database with 1884 plant entries. Some species are represented only by a particular subspecies; variety or cultivar. From this database 'richness' (the number of different plants present in the studied sites) was calculated independently for the Pteridophyta, Pinophyta, dicotyledons and monocotyledons, and for the families, genera, species, subspecies, varieties, forms, cultivars and hybrids. Families representativeness at the Azores' historical gardens, regarding the total of extant families on the world plant list database (The Plant List 2013) was calculated. We also calculated the proportions: of different hybrids and cultivars, of different origins, and of different habit growth forms. 


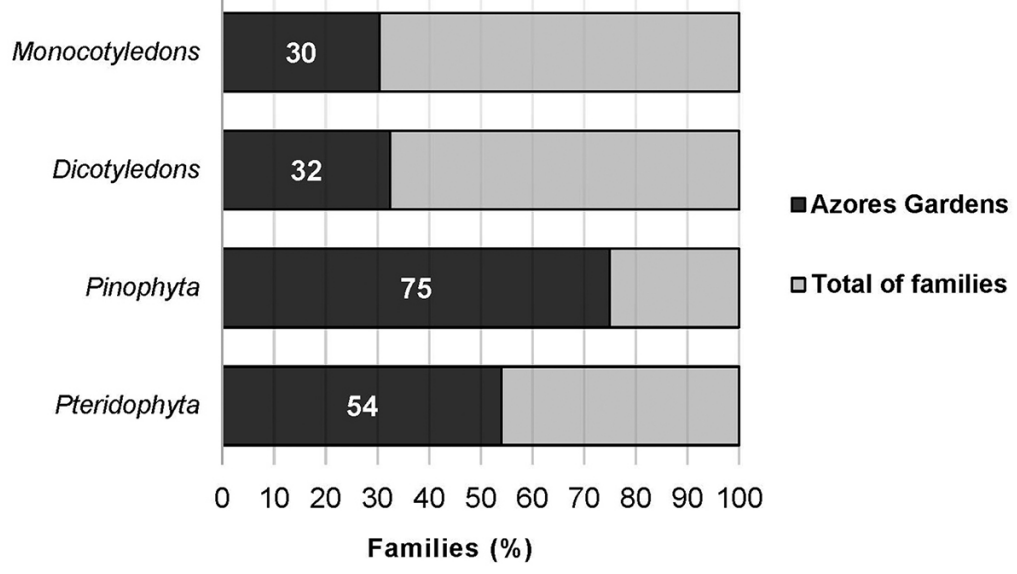

Figure 2. Representativeness of Pteridophyta, Pinophyta, dicotyledons, and monocotyledons families in the Azores' historical gardens (total number of families estimated by The Plant List, 2013).

\section{RESULTS}

The data base analysis reveals 1884 different plant entries that correspond to 168 families, 514 genera, 991 species, 958 cultivars, and 288 hybrids (table 4). Although Pinophyta are the group with the fewest families, in fact they are the best represented group since Azorean gardens own $75 \%$ of the total Pinophyta families registered in The Plant List (2013) database (figure 2). Arecaceae is the family represented by the large number of genera with 19 genera; while Zamiaceae is the family represented by the large number of species with 73 species; also the best represented genera are Encephalartos (with 48 species) and Camellia (with 45 species) (table 5). Camellia hybrids correspond to $60 \%$ of all the hybrids and Camellia cultivars represent $71 \%$ of all the cultivars (table 6 ).

\begin{tabular}{|c|c|c|c|c|c|}
\hline \multicolumn{6}{|c|}{$\begin{array}{c}\text { TABLE 4. RICHNESS VALUES CALCULATED INDEPENDENTLY FOR EACH PLANT GROUP } \\
\text { FOR } 8 \text { HISTORICAL GARDENS AT AZORES ISLANDS (DUQUE DA TERCEIRA, ANTÓNIO } \\
\text { BORGES, SANT'ANA, JOSÉ DO CANTO, AZORES UNIVERSITY, JOSÉ DO CANTO } \\
\text { WOODLAND GARDEN, BEATRIZ DO CANTO PARK, AND TERRA NOSTRA GARDEN) }\end{array}$} \\
\hline Group & Totals & Pteridophyta & Pinophyta & Dicotyledons & MONOCOTYLEDONS \\
\hline Frequency & 1884 & 205 & 138 & 1261 & 280 \\
\hline Families & 168 & 27 & 9 & 108 & 24 \\
\hline Genera & 514 & 61 & 34 & 300 & 119 \\
\hline Species & 991 & 166 & 127 & 492 & 206 \\
\hline Subspecies & 6 & 1 & 0 & 4 & 1 \\
\hline Varieties & 31 & 5 & 2 & 15 & 9 \\
\hline
\end{tabular}




\begin{tabular}{lccccc}
\hline Forms & 3 & 1 & 1 & 1 & 0 \\
\hline Cultivars & $\mathbf{9 5 8}$ & 60 & 11 & 802 & 85 \\
\hline Hybrids & $\mathbf{2 8 8}$ & 2 & 1 & 232 & 53 \\
\hline
\end{tabular}

\begin{tabular}{|c|c|c|c|c|c|}
\hline \multicolumn{6}{|c|}{$\begin{array}{l}\text { TABLE 5. BEST REPRESENTED FAMILIES AND GENERA } \\
\text { AT THE AZOREAN HISTORICAL GARDENS }\end{array}$} \\
\hline FAMILY & $\begin{array}{l}\text { Number of } \\
\text { GenerA }\end{array}$ & FAMILY & $\begin{array}{l}\text { Number of } \\
\text { Species }\end{array}$ & Genus & $\begin{array}{l}\text { Number of } \\
\text { Species }\end{array}$ \\
\hline Arecaceae & 19 & Zamiaceae & 73 & Encephalartos & 48 \\
\hline Myrtaceae & 18 & Theaceae & 48 & Camellia & 45 \\
\hline Asparagaceae & 17 & Bromeliaceae & 46 & Tillandsia & 22 \\
\hline Asteraceae & 17 & Myrtaceae & 43 & Quercus & 16 \\
\hline Fabaceae & 17 & Poaceae & 32 & Blechnum & 15 \\
\hline Poaceae & 17 & Pteridaceae & 32 & Dryopteris & 13 \\
\hline Bromeliaceae & 13 & Asparagaceae & 31 & Pteris & 13 \\
\hline Amaryllidaceae & 12 & Arecaceae & 28 & Cycas & 11 \\
\hline Rosaceae & 11 & Dryopteridaceae & 26 & Polystichum & 11 \\
\hline Cupressaceae & 10 & Blechnaceae & 24 & Acer & 10 \\
\hline Ericaceae & 10 & Ericaceae & 21 & Ficus & 10 \\
\hline Malvaceae & 9 & Fagaceae & 21 & Rhododendron & 10 \\
\hline Pteridaceae & 8 & Fabaceae & 20 & Adiantum & 9 \\
\hline Solanaceae & 8 & Asteraceae & 18 & Cyathea & 9 \\
\hline Zamiaceae & 8 & Cupressaceae & 18 & Eucalyptus & 8 \\
\hline Araceae & 7 & Proteaceae & 16 & Asplenium & 7 \\
\hline Iridaceae & 7 & Sapindaceae & 15 & Vriesea & 7 \\
\hline Polypodiaceae & 7 & Rosaceae & 14 & Aechmea & 6 \\
\hline Acanthaceae & 6 & Moraceae & 14 & Araucaria & 6 \\
\hline Apocynaceae & 6 & Malvaceae & 13 & Bambusa & 6 \\
\hline Lauraceae & 6 & Solanaceae & 13 & Banksia & 6 \\
\hline Oleaceae & 6 & Amaryllidaceae & 12 & Ceratozamia & 6 \\
\hline Pinaceae & 6 & Polypodiaceae & 12 & Macrozamia & 6 \\
\hline Proteaceae & 6 & Oleaceae & 12 & Magnolia & 6 \\
\hline Xanthorrhoeaceae & 6 & Pinaceae & 11 & Salvia & 6 \\
\hline Bignoniaceae & 5 & Lamiaceae & 11 & & \\
\hline Blechnaceae & 5 & Cycadaceae & 11 & & \\
\hline Lamiaceae & 5 & Acanthaceae & 10 & & \\
\hline Moraceae & 5 & Cyatheaceae & 10 & & \\
\hline Sapindaceae & 5 & & & & \\
\hline Remaining families & $\leq 4$ & Remaining families & $\leq 9$ & Remaining genera & $\leq 5$ \\
\hline
\end{tabular}




\section{A. Growth habit (total)}

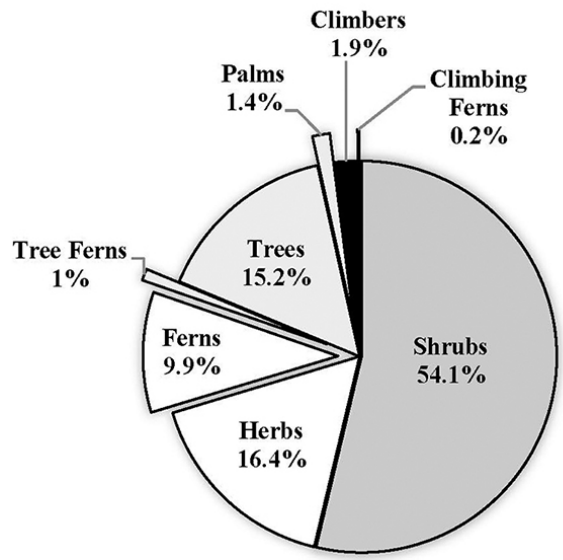

\section{B. Growth habit (species)}

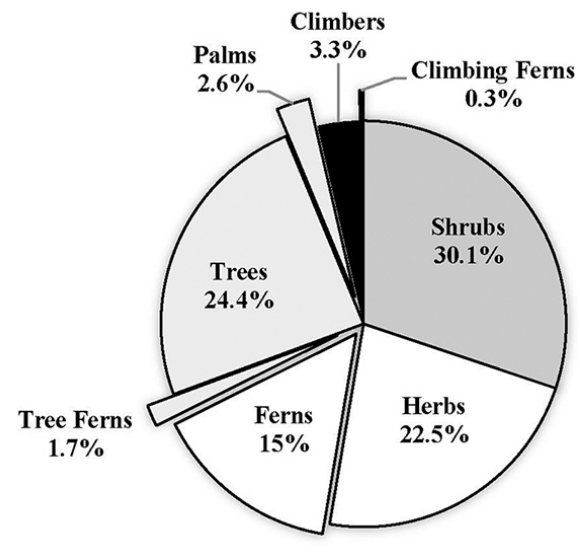

Figure 3. Growth habit distribution for the total of the plant database entries (A) and for the species (B).

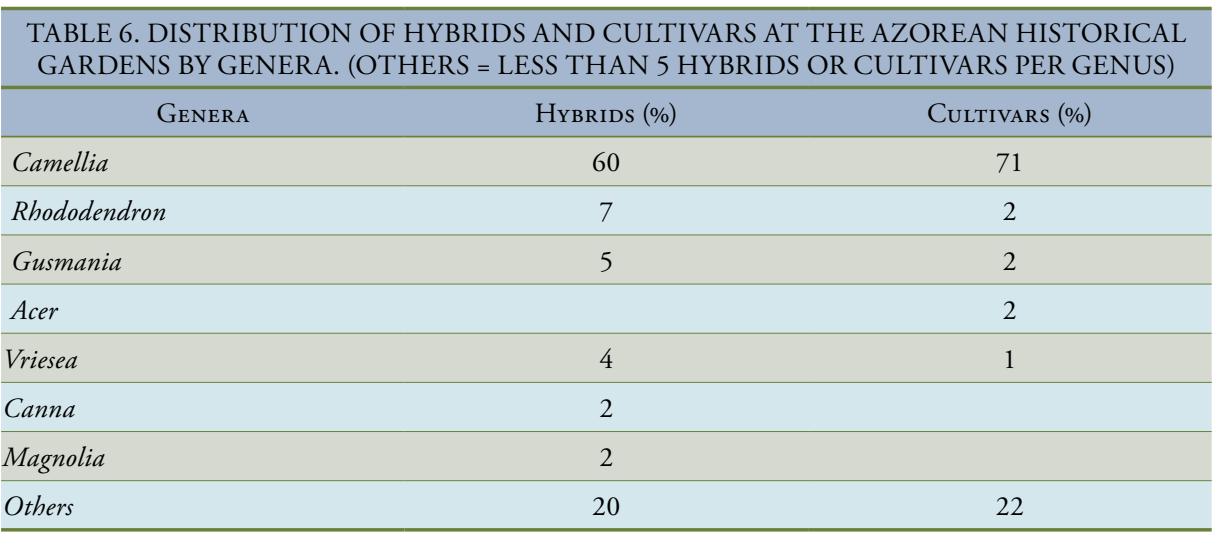

Nearly half (49.2\%) of the data base entries correspond to plants with horticultural origin. Also, nearly half (54\%) of all the entries of the database represent shrubs (figure 3A) but at species level the shrubby growth habit decreases to $30.1 \%$ of the database entries (figure 3B).

Regarding the nativity of plant species Asia is the geographic region best represented in the gardens with 354 species (29\%) of which 254 species are exclusively from Asia, followed by the plants native from the Americas (26\%) (figure 4).

Also, 96 of the species found at Azorean Gardens are under a IUCN (2012) threatened species category. Five species are extinct in the wild (e.g. Encephalartos 


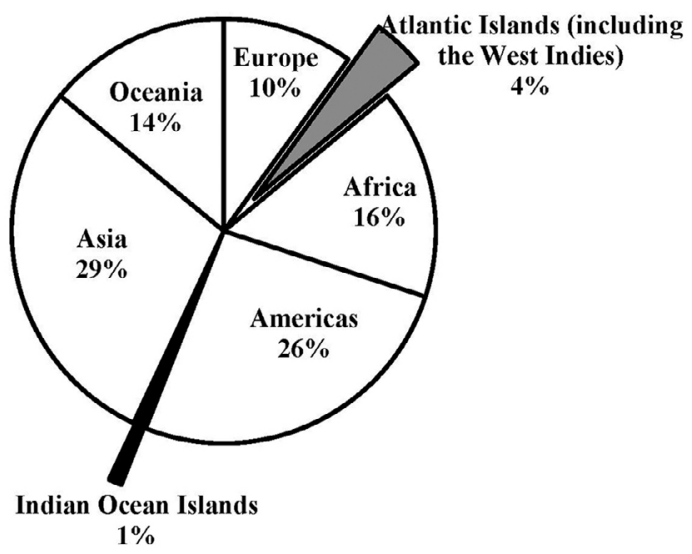

Figure 4. Nativity of plant species found at the Azorean Gardens.

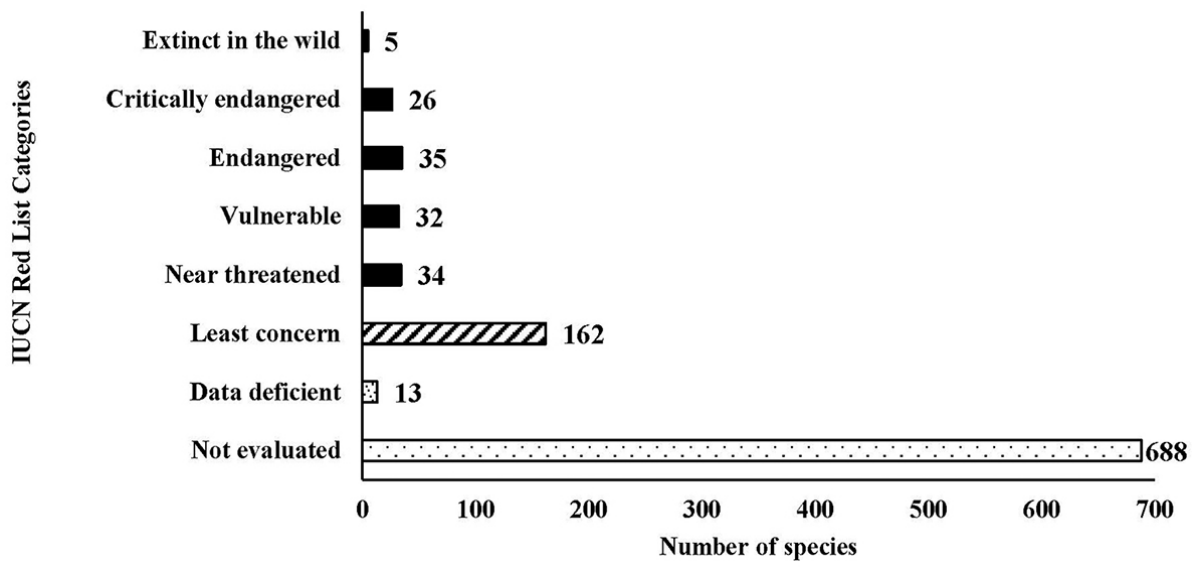

Figure 5. Conservation status: IUCN categories for the species found at the Azorean Gardens.

nubimontanus P.J.H. Hurter and Encephalartos woodii Sander) and 26 species are critically endangered (e.g. Aechmea apocalyptica Reitz, Camellia impressinervis H.T. Chang \& S.Y. Liang, Wollemia nobilis W.G. Jones, K.D. Hill \& J.M. Allen, and Zamia vazquezii D.W. Stev., Sabato \& De Luca) (figure 5).

In a different analysis, 88 species found at Azorean Gardens are naturalized in the Azorean landscape including the worst invasive species at Azores as Pittosporum undulatum Vent. and Hedychium gardnerianum Sheppard ex Ker Gawl. 
Finally, the number of listed species is very different between the surveyed gardens: Terra Nostra Garden possesses the highest number of species, genera and families (respectively 70\%, 70\% and $80 \%$ of the total database entries) (table 7). Also, Terra Nostra Garden possesses the largest collection of Camellia hybrids and cultivars (table 7).

\begin{tabular}{|lccccc}
\hline \multicolumn{5}{c}{ TABLE 7. COMPARATIVE RICHNESS IN THE AZOREAN HiSTORICAL GARDENS } \\
\hline \multicolumn{1}{c}{ CATEGORIEs } & SPECies & GenerA & FAmilies & Hybrids & Cultivars \\
\hline Number of total listed categories & 991 & 514 & 168 & 288 & 958 \\
\hline Terra Nostra Garden & 691 & 360 & 135 & 266 & 859 \\
\hline José do Canto Garden & 283 & 227 & 109 & 7 & 12 \\
\hline José do Canto Woodland Garden & 195 & 144 & 78 & 7 & 16 \\
\hline Sant'Ana Garden & 189 & 140 & 61 & 20 & 34 \\
\hline Duque da Terceira Garden & 134 & 122 & 68 & 6 & 6 \\
\hline Azores University Garden & 100 & 88 & 53 & 4 & 1 \\
\hline António Borges Garden & 62 & 53 & 32 & 3 & 1 \\
\hline Beatriz do Canto Park & 53 & 49 & 34 & 3 & 3 \\
\hline
\end{tabular}

\section{DISCUSSION}

The analysis of the extensive list elaborated by José do Canto in 1856 reveals that a substantial part of the imported plants has been lost. Although this study verified the specimens' existence in the Azorean historical gardens according to the extant lists of plant names, several specimens found on the gardens still lack identification and many ornamental herbaceous plants are not listed. It is also necessary validate the specimens' identification with vouchers properly preserved at registered Herbariums. Therefore, it is expected that the total richness of Azorean gardens will increase with further studies and some specimens may have their identification rectified.

Nowadays the Azorean gardens under public administration tend to preserve the existent specimens while private gardens linked to hotels (Terra Nostra and José do Canto gardens) are increasing their plant collections due to the development of touristic activity.

In relation to the Azores, the island of Madeira has a greater number of historical farms and gardens sooner linked to tourism, which helps to explain, the maintenance of high specific diversity in these gardens (table 8). As in Portuguese mainland (Silva and Carvalho 2015), the preservation of old specimens and the high numbers of cultivated taxa and cultivars in the private insular historical gardens are linked to the resources obtained from the economic activity of tourism (e.g. Parque terra Nostra possesses 1532 plant entries considering all the taxa and cultivars).

Considering the Azorean historical gardens, Terra Nostra Garden possesses the highest number for species specific richness (691), and is comparable in area 
and floristic richness to Quinta do Palheiro Ferreira at Madeira Island (table 8). Due to their mission the Portuguese Historical Botanical Gardens continuous to be the leaders in floristic richness: Madeira Botanical Garden with 3000 taxa, Botanical Garden of Lisbon University with 1086 taxa, and Botanical Garden of Ajuda with 1300 taxa (IFCN 2019; BGCI 2019).

\begin{tabular}{|c|c|c|c|c|c|}
\hline \multicolumn{6}{|c|}{$\begin{array}{l}\text { TABLE 8. PLANT RICHNESS BETWEEN THE PORTUGUESE ARCHIPELAGOS } \\
\text { OF AZORES AND MADEIRA. *DATA FROM QUINTAL (2007) }\end{array}$} \\
\hline & $\begin{array}{l}\text { Historical Gardens } \\
\left(17^{\text {th}}-19^{\text {th }} \text { CENTURIES }\right)\end{array}$ & Area (Ha) & Families (N) & Genera (N) & Species $(\mathrm{N})$ \\
\hline \multirow{8}{*}{ 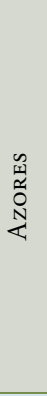 } & Terra Nostra Garden & 12.50 & 135 & 360 & 691 \\
\hline & José do Canto Garden & 5.80 & 109 & 227 & 283 \\
\hline & José do Canto Woodland Garden & 120.00 & 78 & 144 & 195 \\
\hline & Sant'Ana Garden & 7.50 & 61 & 140 & 189 \\
\hline & Duque da Terceira Garden & 1.70 & 68 & 122 & 134 \\
\hline & Azores University Garden & 1.50 & 53 & 88 & 100 \\
\hline & António Borges Garden & 3.00 & 32 & 53 & 62 \\
\hline & Beatriz do Canto Park & 3.70 & 34 & 49 & 53 \\
\hline \multirow{11}{*}{ 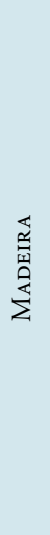 } & Quinta do Palheiro Ferreiro & 14.30 & 136 & 420 & 631 \\
\hline & Quinta Monte Palace & 5.67 & 131 & 339 & 484 \\
\hline & Estalagem Jardins do Lago & 1.37 & 113 & 336 & 433 \\
\hline & Quinta Palmeira & 3.41 & 118 & 313 & 414 \\
\hline & Quinta Jardins do Imperador & 3.85 & 96 & 223 & 284 \\
\hline & Quinta da Magnólia & 2.47 & 95 & 221 & 263 \\
\hline & Quinta da Vigia & 0.56 & 88 & 216 & 260 \\
\hline & Jardim do Hotel Quinta das Vistas & 0.80 & 77 & 159 & 186 \\
\hline & Quinta da Bela Vista & 1.06 & 87 & 171 & 185 \\
\hline & Pousada da Juventude Garden & 0.21 & 73 & 132 & 156 \\
\hline & Hotel Pestana Casino Park Garden & 2.32 & 74 & 142 & 155 \\
\hline
\end{tabular}

Contrarily from the 179 worldwide botanic gardens analysed by Golding et al. (2010), we did not find a correlation (Pearson correlation coefficient $=0,002$ ) between the Portuguese insular historic gardens' areas and the number of plant species (table 8).

At the Azorean historical gardens, the good representativeness of Pteridophyta and Pinophyta families is mainly explained by the fern and Cycadales collections at Terra Nostra Garden. A brief analysis of families and genera representativeness highlight the importance of the 19 genera of palms (Arecaceae) collection on all the Azorean historical gardens, and the important collections of Zamiaceae (73 species) and Camellia ( 45 species) at Terra Nostra Garden. 
Hybrids and cultivars of camellias dominate the lists of hybrids and cultivars present at the Azorean gardens. Once again the collection of camellias at Terra Nostra Garden has 680 plant entries in the total database, placing this garden in the world list of 'Gardens of Excellence' (ICS 2019).

The shrub habit of growth dominates both total entries in the database and plant species. If we considered all the woody plants (shrubs and trees) they represent $69.3 \%$ of the total listed plant names. Nevertheless, the extant lists do not consider many ornamental herbaceous plants.

In spite of the ornamental value of many native Azorean species (Amazon 2019; Future Forests 2019), the local flora is almost neglected at the Azorean historical gardens. The specimens represent probably non planted specimens left in the gardens (as the Picconia azorica (Tutin) Knobl. tree), or result of spontaneous establishment (e.g. the fern Polypodium macaronesicum A.E.Bobrov subsp. azoricum (Vasc.) F.J. Rumsey, Carine $\&$ Robba). For many years only Terra Nostra Garden had a collection of woody Azorean native species. Today, the native Azorean flora is valued in the tourism market and consequently native specimens receive identification tags and plantations of several endemic Azorean species were made in the last years at José do Canto and Terra Nostra private gardens.

The European flora is poorly represented at the Azores historical gardens and embodies only $10 \%$ of the total plant database entries, reflecting one of the European naval expeditions purposes of collecting plants across the Atlantic, Indian and Pacific oceans (Taillemite 2004; Rice 2010). Species native to Asia and/or Oceania represent $43 \%$, of all the species present at the Azorean gardens. At $19^{\text {th }}$ century plants from Asia and Oceania were the novelty since they resulted from the last great expeditions around the world at the end of $18^{\text {th }}$ century; the Araucaria heterophylla tree is a good example, since this coastal species was first seen by Captain Cook from the sea in 1774 on his second voyage around the world (Hooker 1843).

Although the botanical gardens were, in a historical context, responsible for the introduction of many exotic species that later became invasive (Galera and Sudnik-Wócikowska 2010; Hulme 2015; Guo et al. 2019) today many botanical gardens including the historical ones have programs for rare species conservation (Chenabc and Sunabc 2018). In the current Azorean gardens' database only 4.7\% of plant entries correspond to escaped naturalized plants while $5.2 \%$ of plant entries correspond to extinct in wild or under some IUCN (2012) threatened species category. Nevertheless, the percentage of escaped and naturalized plants will increase if we included in the database all the current exotic non-cultivated flora present at the gardens. The recent pressure to recover and improve these historical gardens with new species and cultivars, stresses the importance to perform a risk assessment analysis for any species that is intended to introduce at the gardens (Daehler and Carrino 2000; Groves et al. 2001; Conser et al. 2015). At the same time due to the rarity of many endemic Azorean plants species, the Azorean gardens should play a more important role in their conservation. 


\section{ACKNOWLEDGEMENTS}

To Green Gardens Azores project and the European Regional Development Fund (Operational Programme 'Azores2020'). To Tourism Observatory, Azores University, and Gaspar Frutuoso Institution. To Câmara Municipal de Angra do Heroísmo (Duque da Terceira Garden), Câmara Municipal de Ponta Delgada (António Borges Garden), Direção Regional da Cultura (Sant'Ana Garden), Fundação do Jardim José do Canto (José do Canto Garden), Mata-Jardim José do Canto (José do Canto Woodland Garden), Parque Beatriz do Canto (Beatriz do Canto Park) e Grupo Bensaude (Terra Nostra Garden).

This study was co-financed by the European Regional Development Fund through the Operational Programme 'Azores 2020'.

\section{AUTHORS CONTRIBUTION}

I. Albergaria conceived the present study; R. Raimundo, M.J. Pereira and C. Costa analysed the extant plant lists, locate the plants at the gardens and verify the existing identifications. M.J. Pereira treated the data and took the lead in writing the manuscript but all the authors provided critical feedback.

Recibido: febrero de 2019; ACEPTADo: abril de 2019 


\section{REFERENCES}

Albergaria, I.S. 2000. Quintas, jardins e parques da ilha de São Miguel, 1785-1885. Lisboa: Quetzal Editores 267 pp.

Albergaria, I.S. 2005. Parques e Jardins dos Açores - Azores Parks and Gardens. Lisboa: Argumentum 239 pp.

Amazon, 2019. Campanula vidalii - azorina vidalii - Rosa bis-bis bellflower -20 sementes; [cited 2019 Jun 24]. Available from https://www.amazon.com/Campanula-Vidalii-Azorina-Madeiran-Bellflower/dp/B06Y138DZJ.

Benfield, R.W. 2013. Garden tourism. Wallingford: CAB International 272 pp.

Botanic Gardens Conservation International. 2019. Jardim Botânico da Ajuda. Jardim Botânico da Universidade de Lisboa; [cited 2019 Jun 24]. Available from https://www.bgci.org/ garden_search.php.

ČAKovsKá, B. 2018. Garden tourism: reasons for opening private gardens in the UK National Garden Scheme. Curr. Issues. Tour. 21: 1344-1348.

Canto, J. 1856. Enumeração das principais plantas existentes no meu jardim de Sant'Ana na Primavera de 1856. Ponta Delgada: Historical document.

Carvalho, L.M. 2017. Terra nostra garden. Ponta Delgada: PBF Edition 207 pp.

Chen, G. and Sun, W. 2018. The role of botanical gardens in scientific research, conservation, and citizen science. Plant Divers. 40: 181-188.

Câmara Municipal de Angra do Heroísmo. 2017. Inventário do jardim Duque da Terceira. Angra do Heroísmo: Câmara Municipal de Angra do Heroísmo. Internal Technical Document.

Conser, C., Seebacher, L., Fujino, D., Reichard, S. and Ditomaso, J. 2015. The development of a plant risk evaluation (PRE) tool for assessing the invasive potential of ornamental plants. PLoS One 10: e0121053.

Costa, C. 2018. Inventário botânico do Parque Terra Nostra. Furnas: Parque Terra Nostra. Internal Technical Document.

Cox, M., Chivers, R. and Musgrave, T. 2014. The gardener's garden. London: Phaidon Editors $480 \mathrm{pp}$.

Daehler, C. and Carrino, D. 2000. Predicting invasive plants: prospects for a general screening system based on current regional models. Biol. Invasions 2: 93-102.

Fraga, V. 2014. Tourist destination Azores: Perspectives and strategies to overcome less favourable conditions. Worldwide Hospitality and Tourism Themes 6: 458-465.

Future Forests 2019. Azores blueberry blue pearl; [cited 2019 Jun 24]. Available from https://futureforests.ie/products/vaccinium-cylindraceum-blau-perle.

Galera, H. and Sudnik-Wócikowska, B. 2010. Central European botanic gardens as centres of dispersal of alien plants. Acta Soc. Bot. Pol. 79: 147-156.

Golding, J., Güsewell, S., Kreft, H., Kuzevanov, V., Lehvävirta, S., Parmentier, I. and PauTAsso, M. 2010. Species-richness patterns of the living collections of the world's botanic gardens: a matter of socio-economics? Ann Bot. 105: 689-696.

Governo dos Açores. 2016. Plano estratégico e de marketing para o turismo dos Açores. Secretaria regional do turismo e transportes. Porto: Instituto de turismo $187 \mathrm{pp}$. 
Green Gardens Azores 2019. Green gardens Azores project; [cited 2019 Jun 24]. Available from https://www.otacores.com/greenga/.

Groves, R., Panetta, F. and Virtue, J. 2001. Weed risk assessment. Melbourne: CSIRO Publishing $244 \mathrm{pp}$.

Guerreiro, M. 2017. Azores: more than a tourist destination. Worldwide Hospitality and Tourism Themes 9: 653-658.

Guo, W.-Y., Van Kleunen, M., Pierce, S., Dawson, W., Essl, F., Kreft, H., Maurel, N., Pergl, J., Seebens, H., Weigelt, P. and Pyšek, P. 2019. Domestic gardens play a dominant role in selecting alien species with adaptive strategies that facilitate naturalization. Global Ecol. Biogeogr. 00: 1-12.

Haslemere Travel 2013. RHS Garden holidays; [cited 2019 Jun 24]. Available from https://www. haslemeretravel.co.uk/blog/rhs-garden-holidays/.

Hooker, J.D. 1843. Figure and description of a new species of Araucaria from Moreton Bay, New Holland detected by J.T. Bidwill, Esq. London J. Bot. 2: 498-502.

Hulme, E. 2015. Resolving whether botanic gardens are on the road to conservation or a pathway for plant invasions. Conserv. Biol. 29: 816-824.

International Camellia Society 2007. The ICS Meeting in the Azores $1^{\text {st }}-7^{\text {th }}$ March 2007: An Overall Picture. International Camellia Journal 39: 29.

International Camellia Society 2019. Gardens of Excellence > Terra Nostra Garden, Azores; [cited 2019 Jun 24]. Available from https://internationalcamellia.org/terranostragardens.

Instituto da Floresta e Conservação da Natureza 2019. Jardim botânico da Madeira. No Jardim; [cited 2019 Jun 24]. Available from https://ifcn.madeira.gov.pt/quintas-e-jardins/jardin-botanico-da-madeira-eng-rui-vieira/no-jardim.html.

InTERnATIONAL UNION FOR CONSERVATION OF NATURE 2012. IUCN Red list categories and criteria: Version 3.1. Second edition. Gland and Cambridge: IUCN 32 pp.

Moura, M., Carine, M., Malécot, V., Lourenço, P., Schaefer, H. and Silva, L. 2015. A taxonomic reassessment of Viburnum (Adoxaceae) in the Azores. Phytotaxa 210: 4-23.

National Trust 2014. National trust annual report 2013/14. Swindon: Park Lane Press 88 pp.

Pacheco, J. 2016. Inventário do jardim de Sant'Ana. Serviço de Conservação e Manutenção de Jardins. Ponta Delgada: Presidência do Governo, Região Autónoma dos Açores. Internal Technical Document.

Pereira, M.J., Vieira, V. and Furtado, D. (eds.) 2010. O jardim romântico da universidade dos Açores. Ponta Delgada: Universidade dos Açores 102 pp.

Ponte, J., Couto, G., Pimentel, P. and Oliveira, A. 2018. Tourism activities and companies in a sustainable adventure tourism destination: The Azores. Tour. \& Manag. Stud. 14: 25-38.

Quintal, R. and Braga, T. 2018. Jardim botanico José do Canto - 100 árvores. Lisboa: The Book Hut 199 pp.

Quintal, R. 2007. Quintas, parques e jardins do Funchal, estudo fitogeográfico. Lisboa: Esfera do Caos Editores 702 pp.

Quintal, R. 2015. Mata-jardim José do Canto, lagoa das Furnas - S. Miguel, Açores. Revista Jardins Julho/Agosto 2015: 28-30.

Quintal, R. 2018. Flora of Azorean historical gardens. Ponta Delgada: Green Gardens Azores Project. Internal Technical Document. 
Rice, T. 2010. Voyages of discovery. Sydney: Allen \& Unwin 336 pp.

Sociedade para o Desenvolvimento Empresarial dos Açores 2019. Invest in Azores - Crescimento do setor do turismo; [cited 2019 Jun 24]. Available from https://www.investinazores. com/index.php/pt/porque-acores/setor-do-turismo.

Silva, S. and Carvalho, P. 2015. The Portuguese (historic) gardens as strategic tourism resources in the 21st century. An opportunity to promote, to develop and to preserve. In: Rodrigues, A. (ed.) Gardens and tourism for and beyond economic profit. Évora: CHAIA/CIUHCT, pp. 93-105.

Serviço Regional de Estatística dos Açores 2019. Estatística dos Açores; [cited 2019 Jun 24]. Available from https://srea.azores.gov.pt/default.aspx?lang_id=2.

Taillemite, É. 2004. The discoverers of the Pacific: Bougainville, Cook, Lapérouse. Collection Discovery. Paris: Gallimard 176 pp.

The Plant List 2013. The Plant List, Version 1.1, Published on the Internet; [cited 2019 Jun 24]. Available from http://www.theplantlist.org/.

Topiaris 2008. Identificação da coleção botânica do jardim António Borges-Ponta Delgada. Ponta Delgada: Câmara Municipal de Ponta Delgada. Internal Technical Document. 